\section{Litteraturen og rummet}

Gérard Genette

Det kan synes paradoksalt at tale om rum i forbindelse med litteratur: øjensynligt eksisterer et litterært værk primært $\mathrm{i}$ tid, eftersom den læseakt, hvorigennem vi virkeliggør en skreven teksts virtuelle væsen, består - på samme måde som udførelsen af et musikstykke - af en række på hinanden følgende øjeblikke, der udfoldes $i$ varighed, $i$ vores varighed. Proust viser meget fint dette på de sider $i$ Vejen til Swann, hvor han genkalder sig de søndag eftermiddage i Combray, hvor læsningen, havde tomt den personlige eksistens for middelmådige hændelser" " or erstatet dem med "et ever ser" og erstattet dem med "et eventyrligt liv fyldt ler": eftermiddage, der $\mathbf{i}$ virkeligheden indeholdt dette andet liv, for, som Prous skriver, „efterhånden som jeg skred frem i min læsning og varmen aftog, at lukke det inde $i$ deres tavse, duftende og klare timers langsomt farveskiftende og løvoverskyggede krystal."

Ikke desto mindre kan man også, bør man også, anskue litteraturen ud fra dens forhold til rummet. Ikke kun fordi - det ville være den nemmeste, men ikke den mest interessante måde at betragte dette forhold på - litteraturen mellem så mange andre „emner" også taler om rummet, beskriver steder, boliger, landskaber og, som igen Proust siger det om sin barndoms lesning, i fantasien transporterer os hen til de ukendte landskaber, som den et ojeblik hen tide ulende hnd ver os Illsionen af at passere igennem og bebo. Heller ikke udelulke sensibilite over for rummet eller nærmere fascination af stedet, man ser hos så forskellige forfattere som Hölderlin, Baudelaire, Proust selv, Claudel og Char, er et af de essentielle træk ved dét Valéry kaldte den poetiske tilstand. Der er her tale om spatialitetstræk, som kan optage eller bebo litteraturen, men som måske ikke er forbundet med dens essens, det vil sige dens sprog. Det, som gør malerkunsten til en rumlig kunstart, er ikke, at den representerer det udstrakte rum, men at denne representation selv udføres i de udstrakte rum, i et andet udstrakt rum, som speciel tilhører malerkunsten. Og den rumlige kunstart par excellence, arkitekturen, taler ikke om rummet: det ville være mere præcist at sige, at den får rummet til at tale, at det er rummet, der taler igennem den os (i den udstrækning al kunst $\mathrm{i}$ sidste instans sigter på at organisere sin egen representation) om den. Findes der på samme mide, eller på lignende made, en des div aktiv og ike blot en passiv litterær rumlighed, en ty prasentere og ikke blot repræsenteret rumlighed, der er specifik for litteraturen? Det mener jeg godt, man kan tale om uden at forcere tingene.

Forst og fremmest eksisterer der en slags primær eller elementær spatialitet, som tilhører sproget selv. Det er ofte blevet påpeget, at sproget synes bedre egnet til at "udtrykke“ spatiale relationer end alle andre former for relationer (og dermed er mere anvendeligt til at udtrykke virkeligheden), hvilket får det til at anvende-de spatiale relationer som symboler eller metaforer for virkeligheden, at behandle enhver relation $i$ spatiale termer, $j$ a til at spatialisere alt Det er en kendt sas, at det er denne manialisere alt. Deter ennelfuldal bagrun for Bergsons angreb pà sproget, som i hans øjne e skyldi i et forræden mod "bevidsthedens" væse som primært tidslig. Men man kan sige, at udviklingen inden for lingvistikken de sidste 50 år har bekraftet Bergsons tese på en overbevisende måde, både hvad angår analysen og kritikken: ved skarp at adskille talen fra sprogsystemet og ved at give dette en primær rolle $i$ sprogspillet defineret som et system af relationer, hvor hvert element får værdi alt efter den plads, det indtager i det samlede billede, og alt efter de vertikale og horisontale relationer, som det indgår til nærliggende og lignende elementer. Det er indiskutabelt, at Saussure og hans efterkommere har sat fokus på sprogets spatiale modus, skont det - som Blychot udnyler det-drejers skont det - som Blanchot udtrykker det - drejer sig om en spatialitet, ,hvis originalitet hverken det almindelige geometriske rum eller det praktiske livs rum kan lede os the forstä “.

Denne spatialitet indbygget $i$ sproget som system, der beordrer og bestemmer enhver ytring, manifesterer sig på en vis måde, forstærkes og bliver tydeligere i det litterære værk via skriftsproget. Man har længe betragtet skriften, og især den såkaldte fonetiske skrift sådan som vi opfatter og anvender den $\mathrm{i}$ Vesten, som et simpelt instrument til at nedskrive talen med. Man begynder i dag at forstå, at den er en smule mere end det, og allerede Mallarmé sagde, at „det at tænke er at skrive udèn hjælpemidler". På grund af sin indbygrede spatialitet, som vi lige bar mindet om, er sproget (og dermed som vi lige har minder en slags shift, eller om man vil, shiftens tydelige spatialitet kan forstas som symbol for, at sproget dybest set er spatialt organiseret. Og $i$ hvert fald for os, som lever $i$ en civilisation, hor litteraturen altid er nedskrevet, kan dens rumlige modus ikke betragtes som tilfældig og mulig at overse. Siden Mallarmé har vi lært at anerkende (at gen-kende) grafikkens visuelle potentialer, opsætningen på siden og hele Bogens eksistens som en helhed, og dette perspektivskifte har gjort os mere opmærksomme over for sl-iftens rumlighed, over for tegnenes, ordenes, sætningernes, diskursens atemporelle og reversible placeringer i dén samtidighed, som man benævner teksten. Det er ikke sandt, at lessing blot er dette forlob $i$ er ilke sand, at lasning blot er dette font in sin barnd ins dage fyldt Pá sporet af den tabte tid vidste det uden tvivl bedre end nogen anden, han som krævede en opmærksomhed fra læseren på dét, han kaldte sit værks „teleskopiske" natur, det vil sige på de relationer, som etableres på lang afstand mellem episoder, der står langt fra hinanden $i$ det tidslige forløb af en lineær læsning (men som det er værd at bemærke er tæt på hinanden i det skrevne rum, i sidernes tætte volu- men), og som for at blive forstået kræver en slags simultan perception af værkets totale enhed. En enhed, som ikke kun består af de horisontale relationer af naboskab og følge, men også af relationer, som man kan kalde vertikale og transversale, af virkningene of forventing, af erinding, of rak cirlong, af reaktivn selv sangenly læse som man bør læse sådanne værker (er der andre måder?) er at genlæse, altid allerede at genlæse, ustandseligt at lobe igennem en bog $i$ alle retninger, $i$ alle dimensioner. Man kan således sige, at hverken bogens eller den enkelte sides rum passivt er underlagt den fortløbende læsnings tid, men i den udstrækning, tiden viser sig og fuldt udfoldes i læsningen, ophører bogens og sidens rum ikke med at bøje og omvende tiden og således på en måde ophæve den.

Et tredie aspekt ved den litterære spatialitet udspiller sig po skriftens niveau, denne gang i en silis-

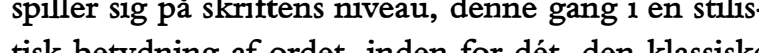
blen klassiske i i dag ville kalde betydningseffekterne. Ytringen formodede temporalitet er forbundet med det lingvistiske udtryks principielle linearitet. Diskursen består tilsyneladende af en række tilstedeværende signifianter, der står ,i stedet for" en kæde af fraværende signifiéer. Men sproget, og især det litterære sprog, fungerer sjældent på en så simpel måde: udtrykket er ikke altid éntydigt, det mangedobler sig hele tiden, det vil sige, at et ord for eksempel på én gang kan have to betydninger, hvorom retorikken sagde, at den ene er bogstavelig, den anden overfort, hvilket resulterer $i$, at det semantiske rum der baer sig vej mellem den tilsyneladende signifé en signifié of entertet. Det er erige nemlig en figur: figuren er på én og samme tid den form, som rummet antager og som sproget giver sig selv, og det er selve symbolet for det litterære sprogs spatialitet i dets relation til betydningen. Der er naturligvis ingen, der længere skriver efter den gamle retoriks kode, men vores skrift er ikke desto mindre gennemhullet af alle slags metaforer og figurer, og 
dét, som vi kalder stilen - selv den mest sobre - forbliver forbundet med de sekundære betydningseffekter, som lingvistikken kalder konnotationer. Det som udsagnet siger er altid dubleret, ledsaget af det som udtryksmåden siger, og den mest transparente måde er stadig en måde. Selv transparensen kan mærkes på den mest indiskrete måde: når Loven som Stendhal setter hojt - udsiger, at enhver dodsdomt fir hovedet hug demt far ho samme tid som det peger pà henrettelsen ogsà pà Lover eget spogs spet pa here bogstavighed. Det er dette "pa samme tid", denne samiaghed der åbnes for og det syn som ses heri, der udgørr stilen som den litterære diskurs' semantiske spatialitet, og denne viser sig som en tekst, som en betydningstæthed, som intet forløb rigtigt kan modsvare og endnu mindre udtømme.

Den sidste form for spatialitet, som man kan nævne, omhandler litteraturen i sin helhed som en kolossal atemporel og anonym produktion. Den væsentligste anke, som Proust fremsatte over for Sainte-Beuve, var denne: Han ser litteraturen under Tidens kategori“. Det kan overaske, at en sadan bejolese kominer fra den forfaterpen der

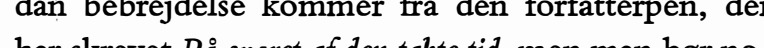
har skrevet Pa sport af an tabe in, men man bornotere sig, at for Proct der er sat ud af hraft. Og had angar hithaturlitikken har Proust varet en af de forste til at protestere mod det diakrone tyranni, som det 19. århundrede og især Sainte-Beuve indvarsler. Ikke for at benægte litteraturens historiske dimension, hvad der ville være absurd, men takket være Proust og visse andre har vi lært at anerkende visse elementer af sammenfald og tilbagevirkninger, der gør, at litteraturen bliver som et stort simultant domæne, som man bør kunne gennemlobe på kryds og tværs. Proust talte om „Mme de Sérionés Dostojevski-sid“" Thiburdet har viet en hel og for nylig har vi lert at lese Ce Kafka: Kafk dene rentegaion af en af huske pà Jules Lemaitres eksemplariske udtalelse om den gamle Brunetière: „Nâr han læser en bog, tænker han, kanne man sige, pa alle de bage, som er blevet skrevet siden verdens begyndelse“". Det er dette, som Borges gør på eminent vis, lukket inde i sit mytiske biblioteks uendelige labyrint, hvor alle bøger er én bog, hvor hver bog er alle bøger.

Biblioteket er nok det klareste og mest trofaste symbol på litteraturens rumlighed. Heri er litteraturen præsenteret, jeg mener til stede, gjort nutidig. mulig at løbe igennem, reversibel, svimlende, hemmeligt uendelig. Man kan sige om den, som Proust in som Proust isin teks Mod Ssermantes" slot "diden har deni taget forn af rum ". En formulening, som ma dil taget form af stilhed.

På dansk ved Britta Timm Knudsen

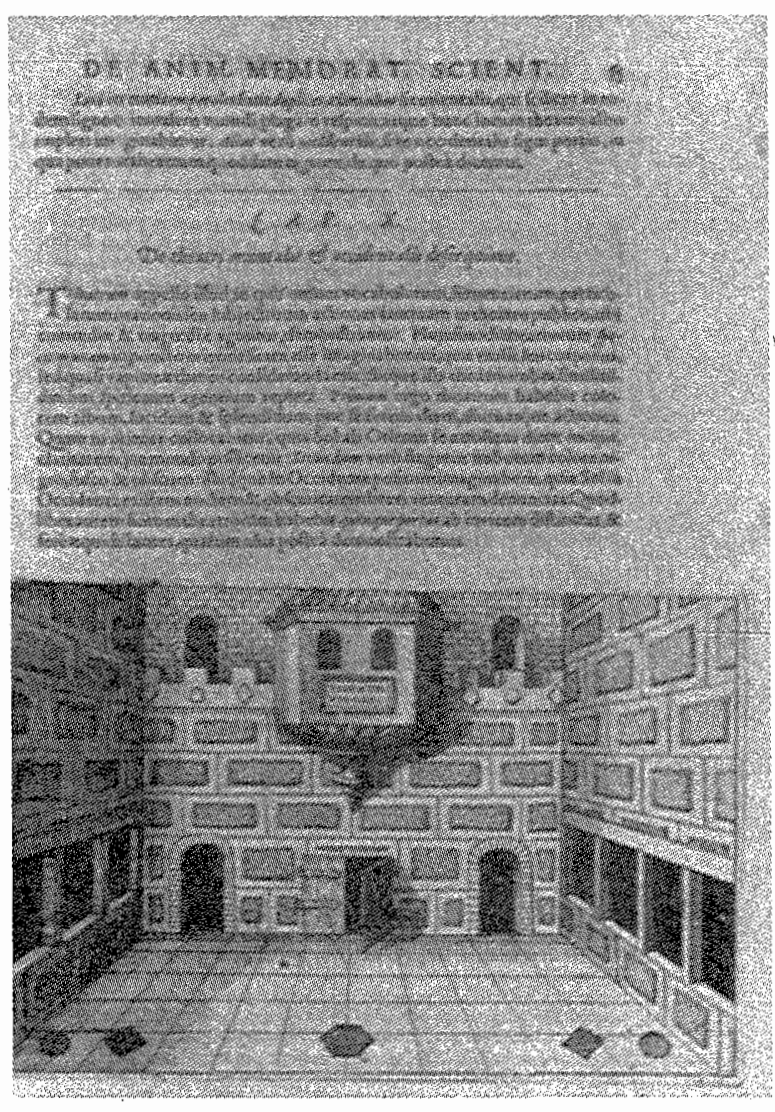
THEATRUM ORBI

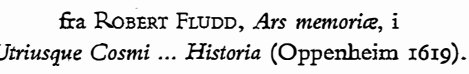

